Carys Davies - Lana Filipin

\title{
Na Commercial Hillu
}

Upoznao ju je, moju baku, Engleskinju, jednog prohladnog ljetnog poslijepodneva na plaži u Southerndownu. Sjedila je na stijeni, na svom kaputu, i pušila cigaretu, a on je - to sam čula od nekoga, od tate ili Mair - bio očaran. Pitao ju je može li sjesti kraj nje i, bez sumnje zato što je bio tako visok i zgodan, pristala je, pa je i on sam zapalio cigaretu, i ona mu je rekla svoje ime, a zvala se Agnes, i on je njoj rekao svoje, a zvao se Will.

Tog su dana njih dvoje šetali po cesti od Southerndowna do Ogmorea i od Ogmorea preko dina u Merthyr Mawru do Ewennyja, gdje su promatrali kako se peče posuda prelivena plavom glazurom, i prije nego što su se razdvojili kako bi ona otišla u hotel u kojem je radila, dopustila mu je da je uzme za ruku.

Vratio se sljedeći tjedan, i tjedan poslije toga, a svaki dan koji se nisu vidjeli pisali su jedno drugome, i nakon četiri tjedna prvi ju je put doveo kući, vlakom do dolina, i ondje je otkrila nešto o njemu što joj nije bio rekao. Možda je to negdje slučajno čula, ili joj je netko rekao baš namjerno, misleći da je to nešto što bi trebala znati. Uglavnom, kad ga je upitala o tome, odmahnuo je rukom i rekao da to nije ništa. Bila je to blesava blamaža koja se dogodila davno i nije značila više ništa sve je to bilo tek priča iz mladosti, nešto tako daleko da jedva može vjerovati da je imalo veze s njim. Ljudi su to uglavnom zaboravili, pa tako i on, i ako joj itko to ikad opet spomene, ne bi se trebala obazirati jer se ni on više ne obazire, a kad je upitala: „Zaista?“ odgovorio je: „Da, zaista.“ Tri mjeseca nakon toga bili su u braku.

Imao je trideset i pet godina, dosta više nego ona, a puno mu je ime bilo William Illtyd Parry. William i Agnes Parry.

Uselili su se u kuću pored zadružnog dućana u Victoria Streetu i imali su troje djece: dva dječaka jednog za drugim, prvo mog oca Emyra, onda mog ujaka Tudora, a potom moju tetu Mair, tri godine poslije. Još uvijek imam fotografiju Willa i Mair - ponovno u Southerndownu. Oboje jedu 
sladoled. Ona nosi ružičasti kupaći kostim s volanima oko stražnjice, a on je zavrnuo hlače malo ispod koljena i na glavi stvarno nosi maramu zavezanu u čvor. Nisam vjerovala da su ljudi to doista radili dok nisam vidjela njegovu sliku. Drži je za ruku. Izgleda sretno. Ne izgleda kao netko kome nešto nedostaje. „Meni je dovoljno“, čini se da govori svojim preplanulim licem i velikim osmijehom, „da stojim ovdje na plaži u Southerndownu na suncu i jedem sladoled sa svojom kćerkicom.“

Radio je na ranžirnom kolodvoru i u nekom je trenutku kupio četverosobnu kuću na Commercial Hillu, koju sam posjećivala kao dijete dok je Agnes još živjela ondje, i ljudi su mi pričali da bi, kad bi u tom razdoblju pričao o svome životu, govorio o dobrim večerama i slatkim okupanim bebama i večernjem miru i tišini. Usrećuje ga, govorio bi, hodati niz visoke pločnike strmih ulica i osjećati planine za leđima, blizinu kuća u dugačkim, stepenastim nizovima, osvijetljene izloge dućana. Nikada nije shvaćao kako netko ondje ne bi želio provesti život. Nije mogao zamisliti bolje mjesto na svijetu.

A onda je stigao dan kad je na ranžirnom kolodvoru dobio promaknuće i navečer su ga Agnes i djeca poslali na sat vremena u Crvenu kravu jer su mu pripremali zabavu - sendviče i papirnate ukrase i tortu sa svjećicama zato što su je, iako nije bio ničiji rođendan, djeca tako preklinjala da se Agnes nasmijala i rekla: „Ma u redu, možemo staviti svjećice.“ To je trebalo biti iznenađenje, no on je znao što spremaju. Mair je provela većinu dana iza kauča uz bočicu ljepila, škare i pakiranje krep-papira. Cijelo poslijepodne slušao je zvuk njezinih pokušaja da bude tiha. Dječaci su se zatvorili u kuhinju s Agnes i satima se čuo zveket posuda i žlica te veseli vriskovi i povici.

I tako je sjedio posve sam za jednim od smeđih lakiranih stolova u otmjenijem dijelu Crvene krave, kad su ušli njegovi prijatelji, Tom Bara i Cy Fish i Jack Midnight i Will America, i svi su djelovali ozbiljno, kao da bi rado nešto izbjegli, a kad je Toma Baru upitao: „No, pa što je, Tome?“, Tom je bacio pogled na ostale, a potom ga oborio i rekao: „Vratila se.“

Često sam ga zamišljala, devetnaestogodišnjaka, kako stoji toga dana u kapelici: tamna valovita kosa obuzdana pomadom, vrat izriban i ružičast od kupke, uštirkana bijela kragna; i čeka. Stoji ondje poput idiota, crven u licu, i znoji se sat i pol; svi šapuću i nakašljavaju se i meškolje i okreću se ne bi li vidjeli je li napokon stigla; neki se ljudi pogledavaju i kimaju da bi dali do znanja da su oni predvidjeli što se sprema, uz takvu djevojku. Svećenika kako mu konačno dodiruje ruku i kaže: „Hajde, Wille, mladiću, možda je vrijeme da odustanemo.“ 
„Gdje je?“ upitao je tada Toma Baru. Tom je odmahnuo glavom i oborio pogled, a onda ga podigao prema vratima koja su dijelila otmjeni dio Crvene krave od vanjskog prolaza.

„Reci joj da se gubi, Wille,“ rekao je Tom, „reci joj da je stigla prekasno.“

Kod kuće Agnes je rekla Tudoru: „Idi po oca, spremni smo.“

No Tudor je nešto petljao s tortom, kao i Emyr; obojica su pokušavali ugurati posljednje svjećice na metalni stalak.

„Idi onda ti“, majka je iz kuhinje doviknula Mair, koja je u dnevnoj sobi još bila zauzeta svojim ukrasima. I tako je upravo Mair otrčala uz brdo do Crvene krave da ga pozove kući; upravo je Mair otrčala uz brdo do neprozirnih staklenih vrata koja odjeljuju vanjski prolaz od otmjenog dijela puba i na pragu naišla na strankinju sa smeđim šeširom; svoga oca koji je ustajao sa stolca, dok su ga prijatelji bez riječi slijedili.

Mair se sjeća kako je stajala ondje, s komadićima krep-papira zalijepljenima za kardigan i ljepljive ručice. Sjeća se da ju je pogledao i zaklopio oči; da je iz prolaza zapuhao lagani povjetarac i podigao mu pokoji pramen kose, koji je pao na ponešto drugačije mjesto, nehajno preko čela. I još se sjeća - Mair, koja je sada stara, Mair, čiji dodir sa sadašnjošću svakim danom sve više slabi, no čija su sjećanja iz prošlosti jasna i bistra i intenzivna i nepromijenjena - Mair se sjeća da je zakročio naprijed iz posve skamenjene sobe prema vratima, širom raširivši ruke i rekavši: „Malena moja."

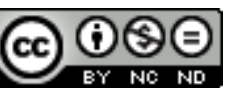

Creative Commons Attribution-NonCommercial-NoDerivatives 4.0 International License 